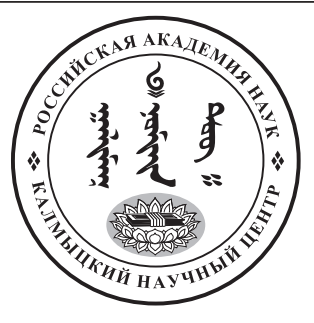

Published in the Russian Federation

Oriental Studies (Previous Name: Bulletin of the Kalmyk Institute

for Humanities of the Russian Academy of Sciences)

Has been issued as a journal since 2008

ISSN: 2619-0990; E-ISSN: 2619-1008

Vol. 13, Is. 2, pp. 385-404, 2020

DOI: $10.22162 / 2619-0990-2020-48-2-385-404$

Journal homepage: https://kigiran.elpub.ru

УДК 910.4, 294.321

\title{
Святыни Утайшаня как объект изучения буддийского наследия
}

\section{Баир Цыремпилович Гомбоев}

${ }^{1}$ Институт монголоведения, буддологии и тибетологии СО РАН (д. 6, ул. Сахьяновой, 670047 Улан-Удэ, Российская Федерация) кандидат исторических наук, научный сотрудник iD 0000-0003-3484-5311. E-mail: barguten@mail.ru

Аннотация. Введение. В буддийской религиозной практике Утайшань как символ пяти священных гор Китая издавна пользовался славой у паломников как одно из самых сакральных мест Восточной и Центральной Азии вслед за Лхасой в Тибете. В статье рассматриваются сакральные объекты Утайшаня и особенности почитания буддийских объектов паломниками (в том числе представителями монголоязычных народов). Целью данной работы является исследование современных локальных форм поклонения буддистов в период посещения религиозных объектов Утайшаня и выявление общего и особенного в их практиках. Maтериаль u методы. Основным источником для данной статьи послужили полевые материалы автора по итогам поездки в 2019 г. в буддийский религиозный и паломнический центр Утайшань провинции Шаньси Китайской Народной Республики. Для сравнительного анализа были использованы материалы по традиционным религиозным представлениям монгольских народов, в частности бурят. В работе применялись описательный метод, историко-сравнительный анализ, а также метод включенного наблюдения. Результаты. В современном мире для многих представителей традиционных религиозных практик в связи с открытием границ стали доступны для визитов и осмотров различные объекты, в том числе религиозные, и появилась возможность посещения особых культовых мест. К таким местам относятся, согласно культурно-историческим традициям бурят, сакральные объекты и на территории этнической Бурятии (например, о. Ольхон и национальный парк «Алханай»), и в соседних государствах (главный буддийский храм Гандан Тэкчилинг в Улан-Баторе, в Монголии, Лхаса и Утайшань — в КНР и др.). В результате первичного исследования выявлена историческая связь священных гор Утайшаня с другими сакральными объектами Восточной и Северной Азии и их религиозно-мифологические параллели. Согласно религиозной традиции, указанные объекты, начиная с Юаньской династии, оказали огромное влияние на развитие буддизма в контексте этнокультурных традиций монгольского мира.

Ключевые слова: Китай, Утайшань, Наньшань, Алханай, буддизм, мифология, сакральные объекты, монголы, буряты, баргуты, паломники

Благодарность: Статья подготовлена в рамках государственного задания (проект XII.192.1.4. «Миф и история в фольклоре и литературе бурят и русских сибиряков: универсалии и специфика», номер госрегистрации № АААА-А17-117021310268-2).

Для цитирования: Гомбоев Б. Ц. Святыни Утайшаня как объект изучения буддийского наследия // Oriental Studies. 2020. Т. 13. № 2. С. 385-404. DOI: 10.22162/2619-0990-2020-48-2-385-404 
UDC 910.4, 294.321

\title{
Wutaishan Shrines as Subjects of Buddhist Heritage Research
}

\author{
Bair Ts. Gomboev ${ }^{1}$ \\ ${ }^{1}$ Institute for Mongolian, Buddhist and Tibetan Studies, Siberian Branch of the RAS \\ (6, Sakhyanova St., Ulan-Ude 670047, Russian Federation) \\ Cand. Sc. (History), Research Associate \\ iD 0000-0003-3484-5311. E-mail: barguten@mail.ru
}

\begin{abstract}
Introduction. In Buddhist religious practice, Wutaishan as a symbol of the five sacred mountains of China has long enjoyed fame among pilgrims as a holiest place in East and Central Asia subsequent to Lhasa (Tibet). The article considers the sacred objects of Wutaishan and features of veneration of Buddhist objects by pilgrims (including representatives of Mongolic peoples). Goals. The work focuses on contemporary local forms of Buddhist worship observed during visits to religious sites of Wutaishan, and identifies the general and specific features of such practices. Materials and Methods. The paper primarily analyzes the author's field materials collected in the course of his 2019 journey to the Wutaishan Buddhist religious and pilgrimage center (Shanxi Province, People's Republic of China). The comparative analysis conducted involves traditional religious ideas of Mongolic peoples and the Buryats proper. The work employs the descriptive method, historicalcomparative analysis, and the method of participant observation. Results. Nowadays, the opening of borders has resulted in that various objects - including religious ones, and particularly special places of worship - have become available for visits and inspections by representatives of traditional religious practices. According to the Buryat cultural and historical traditions, such places include sacred objects both in the territory of ethnic Buryatia (e.g., Olkhon Island and Mount Alkhanay), and in neighboring states (Gandantegchinlen Monastery in Ulaanbaatar, Mongolia; Lhasa and Wutaishan in China, etc.). The primary study reveals certain historical ties between the sacred mountains of Wutaishan and other sacred sites in East and North Asia, and their religious-mythological parallels. The religious tradition says these objects (especially from the Yuan era onwards) have had great impacts on the development of Buddhism in the context of Mongolic ethnocultural traditions.

Keywords: China, Wutaishan, Nanshan, Alkhanay, Buddhism, mythology, sacred objects, Mongols, Buryats, Barga, pilgrims

Acknowledgements: The reported study was funded by government subsidy — project no. XII.192.1.4. 'Myth and History in Folklore and Literature of Siberian Buryats and Russians: Universal and Specific Features', state reg. no. AAAA-A17-117021310268-2).

For citation: Gomboev B. Ts. Wutaishan Shrines as Subjects of Buddhist Heritage Research. Oriental Studies. 2020; Vol. 13(2): 385-404 (In Russ.). DOI: 10.22162/2619-0990-2020-48-2-385-404
\end{abstract}

\section{है}

\section{Введение}

Духовная культура баргутов Монголии и Автономного района Внутренней Монголии Китая в последнее время привлекает все больше внимание исследователей. В 2010 и 2011 гг. во время поездки в г. Хайлар (Хулунбуирский аймак АРВМ Китая) автором были исследованы культовые места старых баргутов (Амбайн обоо), новых баргутов (Шивээ уул, Баян хошуу обоо) ${ }^{1}$. Появилась

\footnotetext{
${ }^{1}$ См.: [Гомбоев 2015: 85-93].
}

уникальная возможность продолжения изучения религиозных воззрений старых и новых баргутов путем расширения границ исследования с целью выявления объектов поклонения баргутов в других районах Китая и Монголии ${ }^{2}$, сакральных объектов и территорий в контексте традиционной культуры монгольского мира и изучения

2 После поездки в Утайшань автору удалось частично выявить культовые места баргутов Восточной Монголии (Дорнодский аймак, август 2019 г.). 
буддийского наследия в целом. В этой статье будет представлена попытка изучения одного из сакральных буддийских центров Центральной и Восточной Азии - Утайшаня - в свете выявления историко-культурных связей баргутского и бурятского населения с сакральным буддийским центром Утайшань.

Поездка к священным горам Утайшаня, находящимся в центральной части Китая в провинции Шаньси близ г. Синьчжоу (в 270 км к юго-западу от Пекина), позволила подойти к рассмотрению актуальных вопросов: мог ли относиться Утайшань к религиозно-сакральному центру буддистов предков баргутов и монголов, каково современное состояние объекта и его культурного ландшафта, а также дала возможность провести фиксацию опыта и современной практики поклонения священным горам и буддийским святыням Утайшаня.

Современное население рассматриваемого нами региона (Утайшань, провинция Шаньси) так же, как и всей Восточной Азии, относится к восточноазиатской группе тихоокеанских монголоидов, представленных северокитайским расовым типом, распространенным у китайцев провинций Шаньдун, Хэбэй, Хэнань, Шаньси, Шэньси и Ганьсу [Этнография 1982: 110].

Известно, что многие баргутские племена (приблизительно с XV по XVIII вв.) были вынуждены оторваться от основного этнического ядра [Нанзатов 2016; Мягмарсамбуу 2018], и теперь их потомки проживают во многих районах Внутренней Монголии и северных и центральных районах Китая. Учитывая, что священные горы Утайшаня являются одними из самых почитаемых в Восточной Азии (здесь расположены и многочисленные буддийские храмы), мы предполагаем, что данный сакральный объект мог быть религиозным центром не только для китайцев и других народов, проживающих вблизи него, но и для представителей

Наһан соогоо нэгэ Түбэд орондо мүргэжэ али Энэдхэг ошожо Далай-ламадаа мүргэхэ ëhomoŭ. Мүнөө үедөө ба ерээдүй наһандаа буян эдлэхэ монгольских народов (монголов, баргутов, калмыков, бурят и др.). Работая в этом направлении, мы берем за основу беседы с представителями старых и новых баргутов, а также других представителей этнической Бурятии. Их предки до установления границ с Монголией и Китаем, а также в более поздний период, вплоть до революции 1917 г., совершали паломнические поездки к священным горам Утайшаня [Сыртыпова 2004: 152, 158]. Сегодня Утайшань является одним из самых посещаемых паломниками буддийских центров и популярных для туристов объектов мирового культурного наследия.

Несколько столетий назад паломники передвигались в основном на верблюдах, лошадях и редко - пешком. Буддисты того времени (100 и более лет назад) активно посещали буддийские религиозные центры Азии, среди которых самым главным для любого буддиста являлся Тибет [Бакаева 2008: 166, 173].

Одним из первых соотечественников под видом буддиста-паломника добрался до Лхасы известный бурятский ученый Г. Ц. Цыбиков, который оставил уникальные научные описания, путевые заметки по Монголии, Тибету, его столице - Лхасе [Цыбиков 1919]. Следует отметить, что ранее Г. Ц. Цыбикова буддистом, достигшим Лхасы (28 февраля 1901 г.) в составе группы путешественников, был калмык О. М. Норзунов. Он получил аудиенцию у Далай-ламы XIII и сделал фотографии Лхасы, которые позже были опубликованы Ж. Деникером и Русским Географическим обществом [Митруев, Воронина 2018: 36].

Прошло более ста лет, однако святыни Утайшаня и Лхасы до сих пор притягивают паломников со всего мира, в частности монгольского происхождения (монголы, буряты, калмыки, а также некоторая часть тувинцев). Буддисты Бурятии, например, говорят:

Один раз в жизни обязательно нужно съездить в Тибет,

помолиться святыням Лхасы,

или в Индию - поклониться Далай-ламе.

Благословение в этой жизни и

удачное перерождение в будущем будет

обеспечено (перевод автора. - Б. Г.). 
Можно представить, например, какое благоговение охватывало жителей и буддистов Бурятии, Калмыкии и Монголии, когда стали возможны визиты в эти регионы духовного лидера буддистов мира Далай-ламы XIV Тензин Гьяцо. Так, 14 июля 1991 г. в Улан-Удэ на центральном стадионе 25-летия Бурятской АССР был проведен посвященный 250 -летию буддизма в России молебен-благословение Далай-ламы [Жуковская 2013: 70-73].

Впервые духовный лидер тибетского буддизма Далай-лама XIV посетил Калмыкию в 1991 г. Этот визит стал важной вехой калмыцкого буддизма [Бакаева 2008: 181]. Известно и о первом визите лидера тибетского буддизма Далай-ламы XIV в Монголию (1979 г.). Визит в Россию Далайламы XIV не может состояться уже более 10 лет [Кузнецова 2008: 280-281]. Часть буддистов на сегодня выбирают паломническую поездку во временную резиденцию Далай-ламы XIV в Северную Индию (г. Дхарамсала) или стараются попасть на лекции Его Святейшества в других странах.

В настоящее время для того, чтобы добраться до Утайшаня, существует множество путей и дорог, возможностей и средств, каким обладает тот или иной путник, паломник или турист. Помимо этого, они выбирают подходящее средство передвижения на любом виде транспорта - воздушный, железнодорожный, автобусный, такси и частные автомобили. Развитию инфраструктуры, увеличению числа паломников и посетителей способствуют включение Утайшаня в список объектов Всемирного культурного наследия, создание условий, сервиса для пребывания и, наконец, непрекращающийся интерес буддистов всего мира к намоленным храмам и культовым местам священных гор Утайшаня.

\section{Материалы и методы}

Известно, что любая наука, в частности этнографическая / антропологическая наука, постоянно нуждается в новых знаниях, новых открытиях, новых подходах. В одной из своих статей российский антрополог С. В. Соколовский, проводя анализ состояния российской антропологии, о роли полевых изысканий справедливо отметил, что за последнее время теряется качество науки в целом в силу разных причин. Одними из причин он назвал отсутствие академических этнографических экспедиций и публикацию научных работ в большей степени с использованием материалов предыдущих экспедиций [Соколовский 2011].

Эту проблему затронул в своей новой работе известный российский фольклорист С. Ю. Неклюдов. Мы согласны с мнением ученого, когда он пишет: «дело касается многочисленных ритуальных действий около каменных или древесных пирамид обо, для их углубленного исследования никакой инструмент, кроме собственных глаз наблюдателя, вообще не годится» [Неклюдов 2019: 9-10].

Изучение истории религии, в частности традиционных религиозных представлений на стыке шаманизма и буддизма на обширной территории от Байкала до Пекина, от Хух-Хото до Хулунбуира, современной ситуации религиозных практик относительно монгольских народов (монголов, баргутов, бурят, калмыков), описание буддийских объектов, наблюдение за паломниками, ознакомление с бытом и культурой (в том числе религиозной) самих носителей культуры непосредственно на священных объектах представляет особый научный интерес, с возможностью проведения антропологического анализа. Большим минусом поездки на территории Центрального Китая можно считать отсутствие переводчика со знанием китайского языка. Хотя стабильная мобильная связь с монголами Китая, определенное знание английского языка, предыдущий опыт (экспедиция в Западную Монголию, Хулунбуирский аймак АРВМ Китая) дали очень многое, по крайней мере все это придавало уверенности в поездке и в работе.

\section{Утайшань - объект паломничества}

Расположенные на Лёссовом плато в северо-восточной части провинции Шаньси горы Утайшань занимают территорию

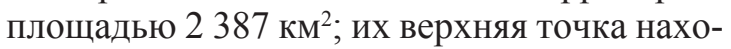
дится на высоте 3058 м над уровнем моря. На Северо-Китайской равнине это самые высокие горы. По нашим наблюдениям, Утайшань окружен пятью плосковерхими пиками без деревьев, горные вершины объединены двумя долинами, где по одной из указанных долин с гор течет небольшая известнякового вида речка [ПМА: инф. 1].

Красота вздымающихся и опадающих хребтов, текущие ручьи и пышная зелень - 
все это делает ландшафт гор Утайшань весьма впечатляющим. Издавна Утайшань привлекал и буддийских паломников, поскольку считался земной резиденцией бодхисатвы Манджушри ${ }^{3}$.

В китайском языке понятия «паломничество» и «священная гора» неразрывно связаны: горы занимают особое место в буддийской иерархии поклонения святым местам. Для монгольских народов гора - это сакральный центр. Как пишет М. М. Содномпилова, «с горами как с культовым объектом в традиции монголоязычных народов связываются идеи родовой и территориальной организации, сохранившиеся в обряде обо тахилга или хада уула тахилга» [Пространство 2008: 185].

Относительно буддийской мифологии, связанной с бодхисатвой Манджушри:

${ }^{3}$ Вэньшушили, Вэньшу - кит. транскрипция санскр. Манджушри. Бодхисаттва, популярный в мифологии махаяны (да шэн) и ваджраяны (ми-цзун). Известен также как Манджугхоша ('Прекрасный Голос'), Манджунатха ('Прекрасный Спаситель'). Его образ, вероятно, возник в последние века до н. э. Он занимает центральное место в «Саддхарма-пундарика-сутре» ('Мяо фа лянь хуа цзин'), где Манджушри говорит о деяниях прежних будд, и в «Вималакиртисутре» ('Вэймоцзе цзин'), где он предстает единственным учеником Будды, по мудрости равным буддисту-мирянину Вималакирти. В «Гандавьюха-сутре» он - один из двух руководителей 500 бодхисаттв и первый наставник главного героя этой сутры - Судханы. В мифологии махаяны Манджушри 70 мириад кальп назад был благочестивым правителем на Востоке. Он решил оставаться бодхисаттвой (пуса) до тех пор, пока не останется ни одного живого существа, нуждающегося в спасении. Манджушри почитался во всех храмах северного буддизма, но особенно в Китае, в провинции Шаньси. Сюань-цзан (сер. VII в.) видел ступу, содержавшую останки тела Манджушри, и связывал его культ с последователями школы йогачары (вэйши-цзун). В йогачаре Вэньшушили почитается как один из семи дхьяни-бодхисаттв. В махаяне Вэньшушили олицетворяет мудрость. Обычно его изображают сидящим на лотосовом троне, держащим в поднятой правой руке пылающий меч, а в левой - книгу. Культ Манджушри был широко распространен и в Тибете, где его земным воплощением считался основатель школы гелугпа Цзонхава (нач. XV в.), а также в Монголии и Бурятии [Мифы народов 1991: 102, 194].
С. Ю. Лепехов отмечает, что в сутре «Хуа янь цзин» ('Аватамсака-сутра') Будда предсказывает, что бодхисаттва Манджушри (Вэньшушили) будет проповедовать на горе, где веет прохладой. В «Вэньшушили бонепань цзин» ('Сутра о паринирване Манджушри') говорится, что Вэньшушили покинул всех бодхисаттв и поселился на горе с пятью пиками. В 662 г. монах Хуй-цзэ из монастыря Хуйчан по указанию императора Гао-цзуна и императрицы У Цзэ-тянь установил, что гора с пятью пиками, являющаяся местом медитации бодхисаттвы Манджушри, - это Утайшань [Лепехов 2007: 629]. По словам информанта Цырен-Норбо (Внутренняя Монголия), данная гора и храм Дайлодин очень популярны для паломников - жителей г. Хух-Хото (столица Автономного района Внутренней Монголии (Китай)) и Монголии. Посещение священных гор Утайшаня буддисты-паломники начинают именно с этой горы, затем по мере возможности переходят на другие объекты [ПМА: инф. 2].

К сожалению, за период пребывания в горах Утайшаня нам не удалось подняться на все указанные пики, осмотреть за одну поездку более сотни священных храмов Утайшаня. Надеемся, что в следующий раз удастся обойти все пять вершин. Мы ознакомились с буддийскими храмами в центральной части, на второй день занялись поиском буддийского монастыря Наньшань, который находился в южной части Утайшаня. Наньшань известен тем, что был построен в период Юаньской династии и непосредственно связан с древней историей монгольских ханов.

В первых веках н. э. в Китай из Индии через Среднюю и Центральную Азию начинает проникать буддизм со своей развитой мифологической системой. Приспосабливаясь к местным условиям, буддизм в Китае включил в свое учение некоторые кардинальные идеи традиционной китайской морально-этической доктрины [Мифы народов 1991: 658].

Помимо этого, пришлые религии впитали в себя различные традиционные местные верования, зачастую переплетаясь с развитыми местными религиями. В народных верованиях китайцев, например, провляются, с одной стороны, черты буддийских представлений, с другой - элементы морально-этического учения конфуцианства 
и исконной китайской религии - даосизма, которая характеризуется чрезвычайно обширным пантеоном, культом отшельничества и ярко выраженным мистицизмом [Этнография 1982: 120].

Согласно материалам С. Ю. Лепехова, наиболее известны следующие монастыри Утайшаня: Сяньтун, Тайюань, Уе, Лохоу, Юаньчжао, Гуанцзун, Пусадин, Цыфу, Саньцюань, Саньта, Шоунин, Дайлодин, Шаншаньцай, Шусян, Пухуа, Линфэн, Вэньшу, Бишан, Цзифу, Цзиньган, Гуанмин, Цифо, Гуанхуа, Пушоу, Баохуа, Мяодэ, Жуйинь, Фогуан, Фэнлинь, Наньшань, Юго, Чжэнхай, Лунцюань, Цинлян, Лохань. При Танской династии (618-907 гг.) в районе Утайшаня действовало наибольшее число монастырей - 360. Их число сократилось до 72 в эпоху Сун (960-1279 гг.). При династии Мин (1368-1644 гг.) монастырей стало 104, при династии Цин (1644-1911 гг.) 100. При республиканском правлении число монастырей увеличилось до 122 [Лепехов 2007: 630].

Как было указано выше, известный отечественный ученый-востоковед, путешественник, профессор Г. Ц. Цыбиков в 1899-1902 гг. совершил свое знаменитое путешествие в Центральный Тибет. Он оставил подробное описание святынь Тибета и ее столицы - Лхасы, но буддийские монастыри Центрального Китая не нашли в нем отражение. Однако в работе Г. Ц. Цыбикова Утайшань упоминается один раз в связи с описанием монастыря Сэра и его основателя Шакчжя-ешея. Так, являясь одним из учеников Цзонхавы, Шакчжя-ешей был отправлен от его имени к императору Минской династии Юн-ло в 1414 г. После выполнения поручений императора по религиозным делам, Шакчжя-ешей в 1415 г. посетил монастырь Утайшаня и в 1416 г. возвратился в Тибет с большим имуществом и ценными подарками, в том числе привез драгоценные четки, которые надел собственноручно на шею большой статуи Чжу в Лхасе [Цыбиков 1981: 183].

Помимо этого, есть упоминание о монахах-бурятах, которые прибывали из Цугольского дацана (Восточное Забайкалье). Для предотвращения нападок на бурят, по личному постановлению Далай-ламы, впредь было указано, что все буряты должны причисляться к Брайбуну или же к Галдану, только монахи из Цугольского дацана при желании могли быть причисленными к монастырю Сэра. Решение Далай-ламы было основано на том, что в Цугольском дацане Забайкалья богословие изучалось по толкованиям сэраского Чойчжи-чжялцана [Цыбиков 1981: 186].

Через несколько лет монастырь Лавран в Северо-Восточном Тибете посещает и другой бурятский ученый Базар Барадийн. Согласно материалам Т. В. Ермаковой, в своем докладе Б. Барадийн отмечает, что «местом исследования был избран тангутский монастырь Лавран, который по своему духовному влиянию на всю Монголию и на наше Забайкалье является крупнейшим из современных центров буддизма, нисколько не уступая в этом отношении самому центру тибетского буддизма - Лхасе» [Ермакова 1998: 118]. Исходя из этих фрагментов описания, можно предположить активное взаимодействие дацанов Забайкалья и Центрального Тибета. Учитывая то, что Утайшань является для монголов и бурят вторым по значимости буддийским религиозным центром после Лхасы, вполне возможно, что представители монгольских племен, в том числе и буряты, посещали монастыри Утайшаня.

Поводом для включения святынь Утайшаня в объект исследований стала беседа со знатоком истории и культуры шэнэхэнских бурят, новых и старых баргутов Хулунбуирского аймака Толтохийн Толто. По его рассказам, он на личной машине с семьей ездил для поклонения святыням Утайшаня. Он вспоминал беседы с пожилыми баргутами о том, как раньше они ездили молиться в Утайшань. Говоря о времени поездки, его собеседники указывали, что это было примерно до культурной революции в Китае, в начале 1960-х гг. По тем временам паломников было гораздо меньше, но и добираться было очень сложно. Некоторые из них поднимались на все пять вершин Утайшаня, однако более пожилые граждане ограничивались несколькими монастырями сакрального центра. Некоторым паломникам удавалось поклониться в священных храмах Тибета, а многие буддийские священнослужители ездили за благословением в центр тибетского буддизма в Лхасу. Позже пожилые сородичи ему рассказывали, что благодаря поездкам в сакральные буддийские центры беды обошли стороной их семьи, потомки 
достойно определились в жизни и живут хорошо. По словам информанта, в настоящее время многие святыни Утайшаня стали более доступными, да и дорога стала намного лучше [ПМА: инф. 1].

Культ Манджушри был широко распространен и в Тибете, где его земным воплощением считался основатель школы гелугпа Цзонхава (нач. XV в.), а также в Монголии и Бурятии. Буддийское божество Манджушри проявляется во многих местах, в частности, в главных монастырях Тибета. Так, Г. Ц. Цыбиков, упоминая Манджушри несколько раз в своей работе, отмечает, во-первых, легенду о появлении ряда божеств (Львиноголосого, Манджушри, Ямантаки, Махакалы) на листьях сандалового дерева «цан-дан» на месте нахождения главной святыни-ступы в монастыре Гумбум [Цыбиков 1981: 43] примерно через три года после основания самого монастыря (1357 г.). Во-вторых, вследствие наступления китайцев в Тибет местные монахи поставили большую статую Чжу как главную святыню Лхасы. В южных зеркальных дверях храма Чжу нарисовали при этом изображение Манджушри, возможно, для защиты основной статуи. В-третьих, исследователь отмечает, что в храме Чжу, по преданию, на шероховатой поверхности стены появился нерукотворный образ Манджушри с мечом в правой руке и книгой на лотосе в левой [Цыбиков 1981: 79-80]. В четвертых, по Г. Ц. Цыбикову, при провозглашении маньчжурского полководца Тайцзуна было использовано название божества «Великий Хуанди-Манджушри». В пятых, в маленькой часовне на плите самостоятельно выступило изображение троицы «Ригсум-гоньбо», т. е. Чжамьяна, Чагдора и Чжан-рай-сига (Манджушри, Ваджрапани и четырехрукого Авалокитешвары) [Цыбиков 1981: 168]. И последнее упоминание божества связано с тем, что образ Манджушри, по преданию, явился в то время, когда основатель монастыря Брайбун (Даший-балдан, 1416 г.) жил в этой келье.

В Монголии, по С. Ю. Неклюдову, помимо Бурхан-багши (Будды Шакьямуни), в небольшую группу фольклорных «бурханов-демиургов», творцов мира и человека входят Майдар (Майтрея), Манзшир / Манджушир (Манджушри), Арья-Бало (Авалокитешвара), Очирвани (Ваджрапани) [Неклюдов 2019: 300].
Таким образом, изображение Манджушри постоянно сопровождает либо главных основателей буддизма, либо духовных лиц как защитник, как божество-хранитель. Но есть и другое предположение, связанное с темой нашего исследования, - лик Манджушри магическим образом появляется на святых местах (монастырях, ступах, кельях), становится покровителем отдельных природных ландшафтов. Это можно связать с почитанием Манджушри как покровителя на священных горах Утайшаня (Китай) и Алханая (Россия, Забайкалье), возможно, в некоторых местах и дацанах этнической Бурятии. Изучая иконографию буддизма, упоминал о бодхисаттве Манджушри в своих трудах этнограф и краевед Дмитрий Першин ${ }^{4}$ [Кузьмин 2014: 86, 88]. Так, в музее-усадьбе В. П. Сукачева в Иркутске на одной из экспозиций постоянной выставки представлен его рукописный документ ВСОРГО, датированный 27 сентября 1898 г., где указывается, что «Манджушри символизирует мудрость, а потому считается покровителем правосудия» [ПМА: инф. 3].

В работе Н. Ц. Мункуева есть упоминание о том, что существует одна статья Чэнь Юаня, посвященная религиозным взглядам Елюй Чу-Цая (советника Чингис-хана), который был свидетелем или участником многих событий, происходивших при монгольских ханах в Монголии и Северном Китае [Мункуев 1965: 9].

Согласно китайским источникам, после переписи монгольский хан Угэдэй решил раздать во владение своим родственникам и видным представителям военной знати население обширных районов Северного Китая. Одним из отданных уделов монгольской знати стал округ Синьчжоу вокруг современного города Синтай провинции

4 Першин Дмитрий Петрович (1861-1936) - известный сибирский краевед, этнограф, публицист и журналист. Он принимал активное участие в деятельности ВСОРГО: собирал коллекции на естественно-научные темы, читал лекции по буддизму и шаманизму. Особенно большой общественный резонанс имели его воскресные лекции по ламаизму при краеведческом музее. Известно, что в восточной религии его больше всего интересовала иконография буддизма. 
Хэбэйร. Примерно в это же время были проведены мероприятия по переписи населения и хозяйственных дворов (4 августа -1 сентября 1236 г.). В Северном Китае насчитывалось 1830 дворов, из них в вышеназванном округе было около 1100 дворов [Мункуев 1965: 47].

Исходя из этого очевидно, что земли провинции Хэбэй входили в состав древнемонгольских земель. К тому же округ был густонаселенным, согласно ханскому уложению «О повинностях служителей культов», в рассматриваемый период они были освобождены от всяких фискальных обязанностей перед государством, т. е. монгольским ханским двором [Мункуев 1965: 54]. Для сравнения: монастыри Утайшаня сейчас насчитывают более 100 объектов и религиозных комплексов, что характерно в период туристического расцвета округа и почитания буддийских святынь.

Отметим, что основной поток туристов и паломников Монголии и Внутренней Монголии на Утайтань идет через современный город Датун (при династии Юань город носил имя Юньчжун). От других городов Китая и Внутренней Монголии транспортная инфраструктура развита и представляет собой сеть авиасообщений, железнодорожных путей $u$ автомобильных дорог. От г. Датун до святынь Утайтаня в основном курсируют автобусы большой $u$ малой вместимости, такси и частные легковые автомобили. За день контрольный пункт Утайшаня проезжает более 100 автобусов большой и малой вместимости, более тысячи легковых машин ${ }^{6}$. На сегодня святыни Утайтаня входят в список объектов Всемирного культурного наследия. И на каждом монастыре и храме у входа висит табличка с указанием данного статуса [ПМА: инф. 2].

В настоящее время ведется строительство новых монастырей и реконструкция

5 По всей видимости, речь идет о территориях, находящихся близко к монастырю Утайшань.

${ }^{6}$ Для сравнения: Иволгинский дацан в Бурятии в период туристического сезона посещает около 10 автобусов разной вместимости и более 200 легковых автомобилей в день. Завод по производству отечественных игристых вин «Абрау Дюрсо» в Краснодарском крае в сезон пропускает более 30 автобусов большой вместимости и более 300 автомобилей в день. старых. Утайшань является уникальным местом тысячелетнего взаимодействия китайского, тибетского, монгольского и маньчжурского буддизма. Результат этого взаимодействия проявлялся как на доктринальном, так и на религиозно-практическом уровнях. Императоры нескольких династий неоднократно совершали паломничества на Утайшань. Монастырь Пусадин, построенный при императоре Сяо-вэне (471-499 гг.) Северовэйской династии, одно время был временной императорской резиденцией Цинской династии (по причине чего его крыши крыты золоченой черепицей). В монастыре установлены стелы императоров Кан-си (1654-1723 гг.), Цянь-луна (17361795 гг.) и Цзя-цина (1760-1820 гг.) [Лепехов 2007: 629].

Утайшань, имея многовековую историю развития традиционных религиозных воззрений и буддийской составляющей, на современном этапе представляет собой грандиозный туристический объект, признанный шедевром мирового культурного наследия. Все это дает Китайской Народной Республике возможность использовать в полной мере крупный буддийский духовный центр не только для религиозных паломников, но и для многочисленных туристов. Многие искушенные туристы готовы увидеть воочию Утайшань, ознакомиться с природными и культурными шедеврами. Однако с точки зрения науки не менее актуальным становится изучение древнего архитектурного, исторического и культурного наследия, в том числе в призме этнических, социальных, культурологических и других проблем современности.

Центральная часть Утайшаня состоит из множества буддийских храмов и монастырей, инфраструктурных объектов, ресторанов, магазинов, сервисных центров, туристско-развлекательных сооружений, включая транспортно-логистический узел.

Попасть в центр Утайшаня можно только через центральный офис (рис. 1), причем для пассажиров имеется отдельный вход (с оплатой 150 юаней), а автобусы и иной транспорт проезжают через автомобильный пункт (более 250 юаней). Далее через десять километров по асфальтированной дороге они добираются до центра. Здесь на конечном пункте пассажиры высаживаются и обустраиваются в местных гостиницах, которых начиная с 
города Тайхуай великое множество по обеим сторонам дороги. Ценовая категория - от 100 до 400 юаней в сутки, в зависимости от условий проживания и отдаленности от центра. Курсируют автобусы по внутреннему маршруту, частные такси за определенную плату довозят до нужного места.

Согласно нашим наблюдениям, среди паломников, туристов в основном встречаются представители китайского народа. Европейцев, судя по антропологическим чертам, намного меньше (5-6 \%). При приеме пищи в гостинице мы наблюдали следующую ситуацию: большая китайская семья заказывает полный набор китайских блюд, компания из испанских туристов заказывает пиво и семечки, а нам по заказу принесли суп из мяса, картошки и овощей, чай. Причем мясо было сырое, нам пришлось попросить примус и довести суп до нормальной готовности. Хозяин кафе на ломаном английском сказал, что так примерно заказывают в основном монголы.

Паломников можно отличить по одежде, языку, по темпераменту и поведению. По приблизительной оценке, в этой милли- онной толпе количество приезжих может варьироваться в пределах 2-3 \%. В основном приезжие паломники и туристы ходят по монастырям организованными группами, а местные китайцы - семьями, локальными группами. Наше желание попасть в монгольские группы и найти обустройство у монголов не увенчалось успехом. Хотя о том, что существуют монгольские дешевые гостиницы и монгольские гиды, нам было сказано еще в столице Внутренней Монголии - в г. Хух-Хото. Однако найти их оказалось не так просто. Обращение к случайным прохожим, волонтерам на различных ресепшн-стойках на трассе не дало нужного результата. Нам осталось ознакомиться с монастырями в центре и обойти буддийские храмы в индивидуальном порядке.

\section{Храмы Утайшаня}

Одним из первых объектов для нашего ознакомления стал буддийский храм (рис. 2), где самым популярным объектом является зал Будды после ияветения. Этот зал имеет пять входов и двойные карнизы для двух этажей с крышей в китайском архитектурном стиле. В центре зала располо-

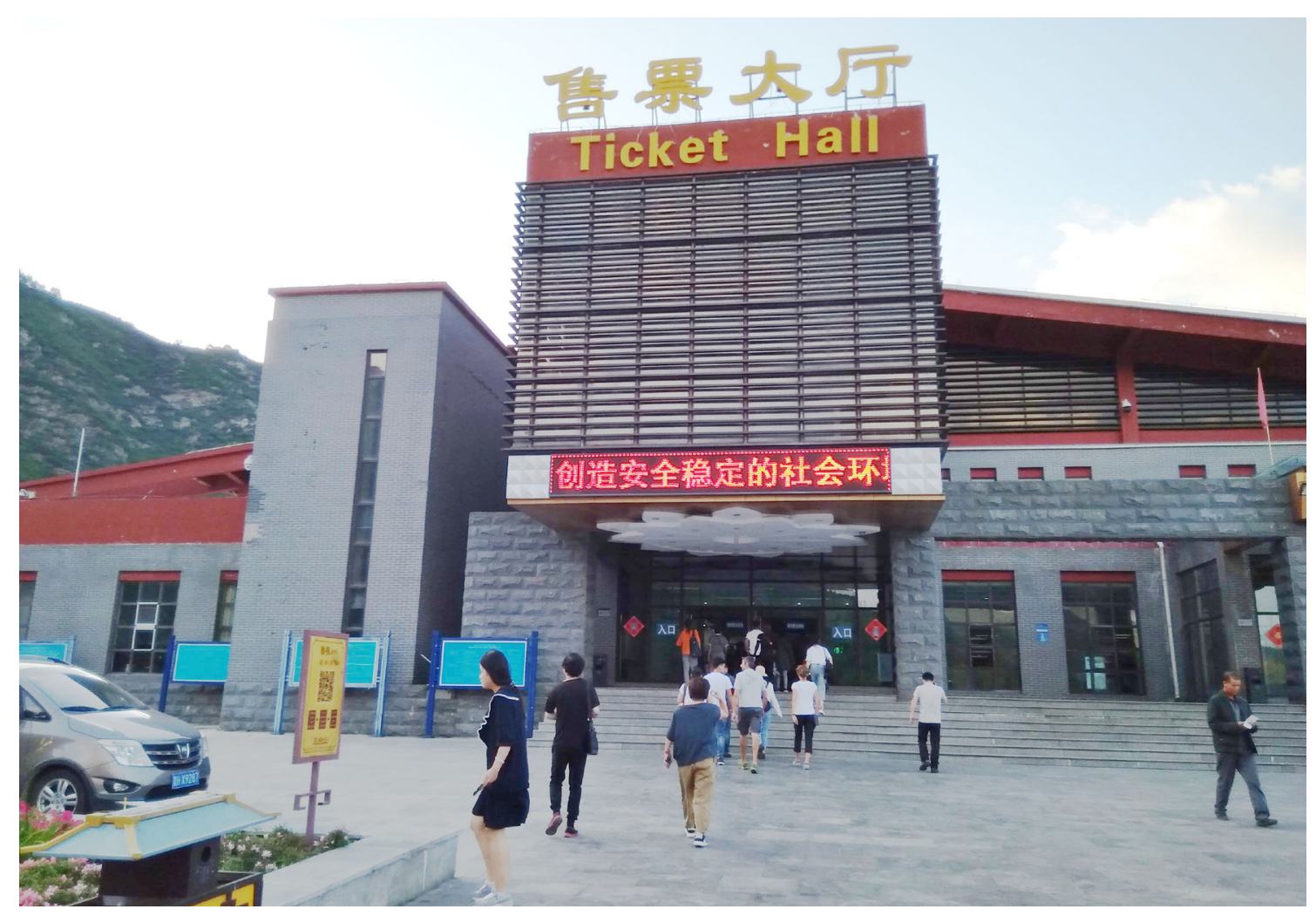

Puc. 1. Утайшань. Центральный вход для пассажиров. 2019 г. Фото автора

[Fig. 1. Wutaishan. Central entrance for passengers. 2019. Photo by author] 
жена квадратная кирпичная платформа с деревянным диском посередине, на котором выгравированы волны, которые можно представить как море или океан. За пределами диска вытиснены лики восемнадцати архатов, как будто идущих по морской волне, согласно схеме «двадцати четырех небес». В середине диска помещён высокий деревянный цветок лотоса, а его ствол поднимается на второй этаж. Диск состоит из 8 частей - лепестков лотоса. Внутри лотоса представлены скульптуры четырех Будд, находящихся спиной друг другу - это Будда Шакьямуни, Будда Амитабха, Будда Медицины и Майтрея. К сожалению, внутри зала фотографировать не разрешается.

По желанию и разрешению настоятеля (дежурного монаха) паломники могут использовать механизм для управления диском вручную. Управляя этой машиной, можно наблюдать открытие и закрытие цветка лотоса. Когда раскрываются лепестки лотоса, появляются лики Будд, и благодаря этому процессу посетители называют

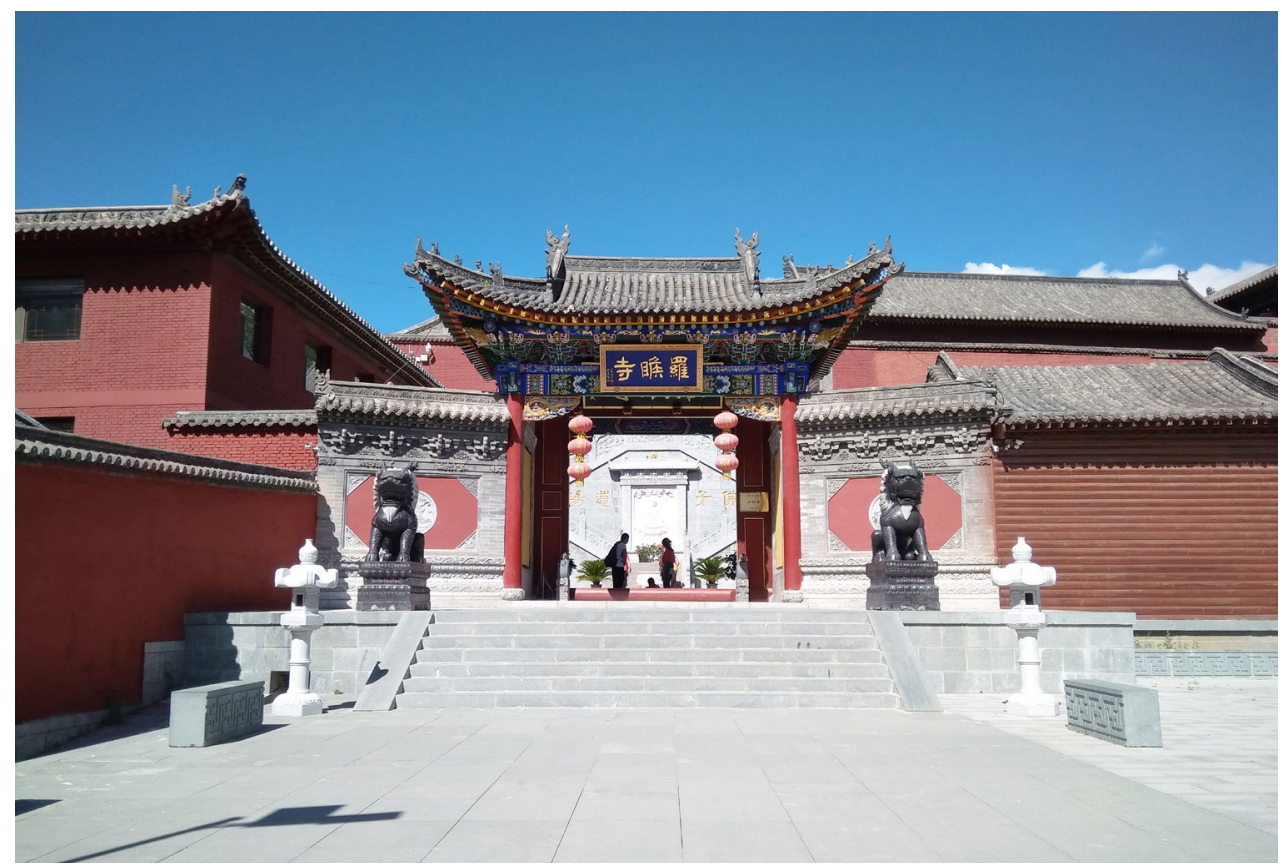

Puc. 2. Утайшань. Буддийский храм, где находится зал «Будда появляется после цветения». 2019. Фото автора

[Fig. 2. Wutaishan. Buddhist temple, where there is a hall «Buddha appears after flowering». 2019. Author's photo]

этот зал «Будда появляется после цветения». Данный процесс появления Будды превратил зал во всемирно известный проект. Дерево, которое произрастает в храме и добирается до второго этажа, окружено восемью решетками. За каждой решеткой есть статуя Будды. В зале возле стены посетители поклоняются бодхисаттве Авалокитешваре и Ваджрасаттве. За решетками также находится Трипитака (свод раннебуддийских священных текстов) на китайском, монгольском и тибетском языках. В северной части второго этажа посетители поклоняются Будде. По четырем стенам расположены сотни статуэток Будды и других буддийских божеств. Вокруг здания, где находится этот зал, функционирует много промежуточных залов и помещений, в центре каждого из которых находятся по два буддийских божества (в основном либо два, либо четыре). Во дворе между этими помещениями находятся строения, где посетители и паломники зажигают лампаду (бур. зула бадарааха). Перед храмом расположены цилиндры, внутри которых помещены тексты с буддийскими мантрами (бур. хүрдэ). Здесь же на площадках располагаются группы паломников, зачастую повторяющие вслед за своими учителями буддийские молитвы и мантры (рис. 3 ). 
Что касается подношений божествам, паломники и посетители оставляют у каждой статуэтки мелкие купюры (по 5-10 юаней), но в основном по 1 юаню. В каждом зале внутри здания или храма находится буддийский монах-смотритель, и при желании посетителей он тут же приглашает их на индивидуальный прием. Встречаются

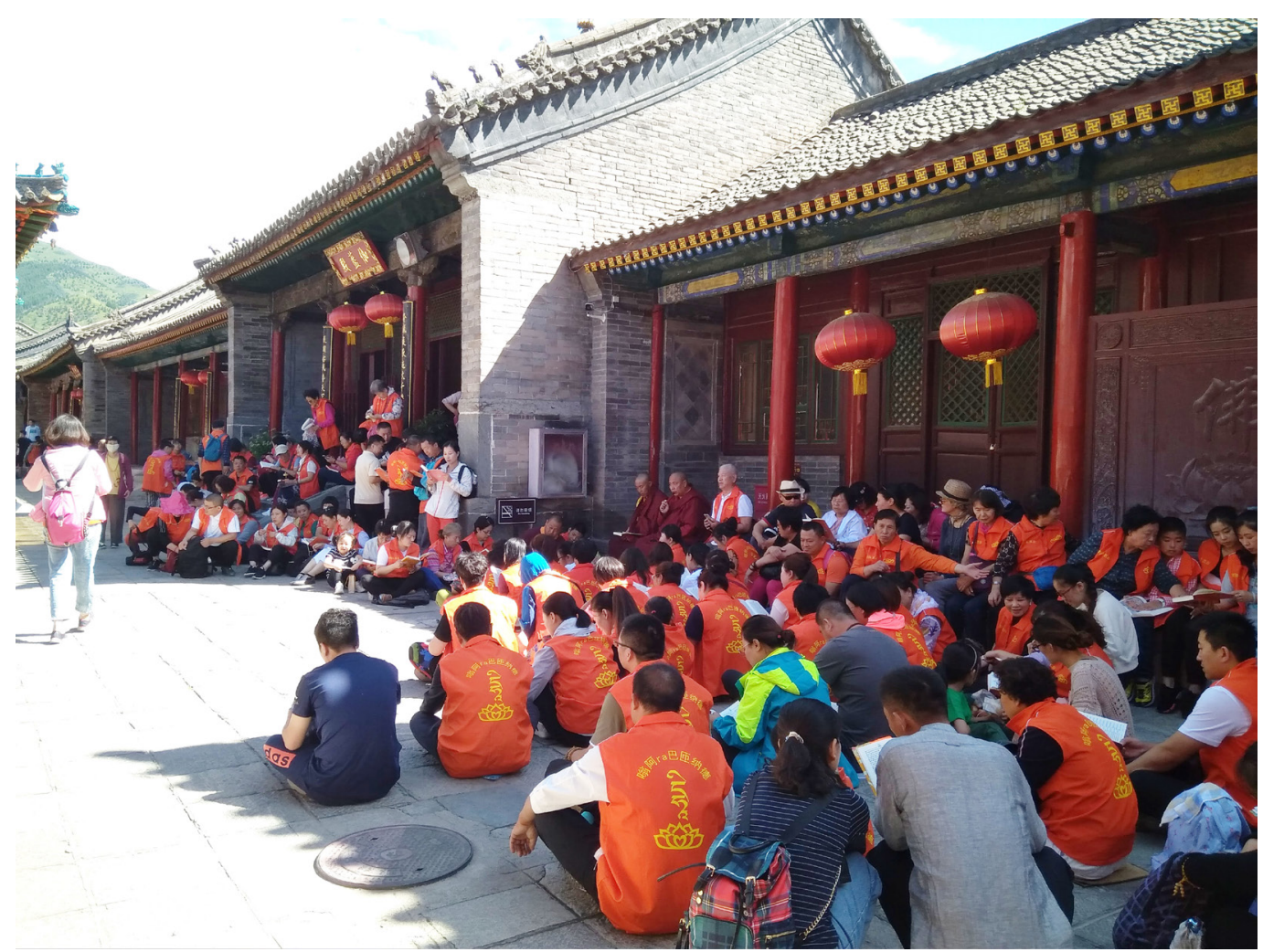

Puc. 3. Утайшань. Группа китайских паломников во дворе одного из храмов. 2019. Фото автора

[Fig. 3. Wutaishan. A group of chinese pilgrims in the courtyard of one of the temples. 2019. Author's photo]

разные посетители: паломников сразу видно с их неподдельной набожностью, они поклоняются каждому божеству, оставляют денежные купюры разного достоинства, остальные обходят залы как обычные туристы. Перед каждым храмом находятся ритуальные чаши для подношений пищей, возжигания благовоний - курильницы (бур. сан табиха).

В центральной части Утайшаня находится канатная дорога (стоимость подъема и спуска - 100 юаней), поднимающая посетителей для осмотра местности на одну из гор. За верхней точкой канатной дороги находятся несколько буддийских храмов, расположенных на террасах. На промежуточных возвышенностях видны буддийские ступы (субурганы). С высоты появляется красивый обзор местности, особенно вид на центральную пагоду-храм (главный символ Утайшаня). Между двумя горными возвышенностями протекает бурная речка, по берегам которой и находится вся основная инфраструктура: автовокзал, гостиницы, рестораны, таксопарк, центр транспортной сети, откуда расходятся главные магистрали к пяти главным вершинам окрестных гор Утайшаня.

В середине священных гор Утайшаня расположен один из самых заметных объектов на фоне буддийских монастырей - пагода Дабай (или Таюаньсы). Данный культовый комплекс географически находится между канатной дорогой, автовокзалом и компактно расположенными гостиницами и фуд-центрами, приблизительно в ста метpax от основной дороги. На площадке перед входом расположены многочисленные 
торговые лавки, где продаются ритуальные предметы для подношений, китайские сувениры, еда и мн. др. Из общей массы ритуальных предметов больше всего привлекают внимание благовония (ароматические палочки), упакованные в коробки. После их приобретения китайцы держат перед собой аромапалочки и делают поклоны четырем сторонам света. Указанные благовония паломники и туристы преподносят в буддийском храме (по одной или несколько упаковок). Некоторые из них сами зажигают благовония и оставляют их на алтарях, после чего подходят к смотрителям или монахам, обращаясь к ним с различными просьбами, садятся за стол где-нибудь в углу. По окончании беседы подносят монаху деньги и удаляются из храма либо продолжают совершать обход, поклоняясь божествам.

Если сравнить с бурятскими или мон- го весьма привлекательна, особенно когда находишься вблизи объекта. Пагода имеет тринадцать «слоев» (в верхней части объекта), под названием «Тринадцать небес». На пагоде сооружено навершие высотой 4,52 м, на котором даже растет маленькое деревце. Пагода Дабай представляет собой уникальный архитектурный и исторический объект, приметна с любых сторон и потому стала общим символом для всего Утайшаня - объекта мирового культурного наследия (рис. 4).

По одной легенде, пагода опустилась на землю прямо с небес в подобном виде, по другой пагода была построена еще в III в. до н. э. индийским царем Ашокой, покровителем и распространителем буддизма.

По углам религиозного объекта находятся беседки, сооруженные согласно трагольскими верующими, то следует отметить: приезжая в любой дацан, они приобретают шелковые шарфы-хадаки, заказывают молебен и в конце оставляют деньги монахам. При этом, если понадобится на тот или иной молебен ритуальная пища и обрядовые напитки, то все это подносится все вместе в строгой последовательности - ритуальный шарф-хадак, ритуальная пища и деньги.

При посещении некоторых храмов на входе от посетителей не берут денег. Однако на входе в монастырь Дабай с нас потребовали 15 юаней, предложили буклет на китайском языке и только после этого, собрав 10 человек, группой запустили через турникет.

Согласно информации на объекте, пагода называется «Башня буддийских реликвий Шакьямуни». Она была построена мастерами из Непала в 1301 г., а затем была перестроена в 1581 г. Высота пагоды составляет 56,37 м. Пьедестал пагоды - октагон, оригинальная форма которо-

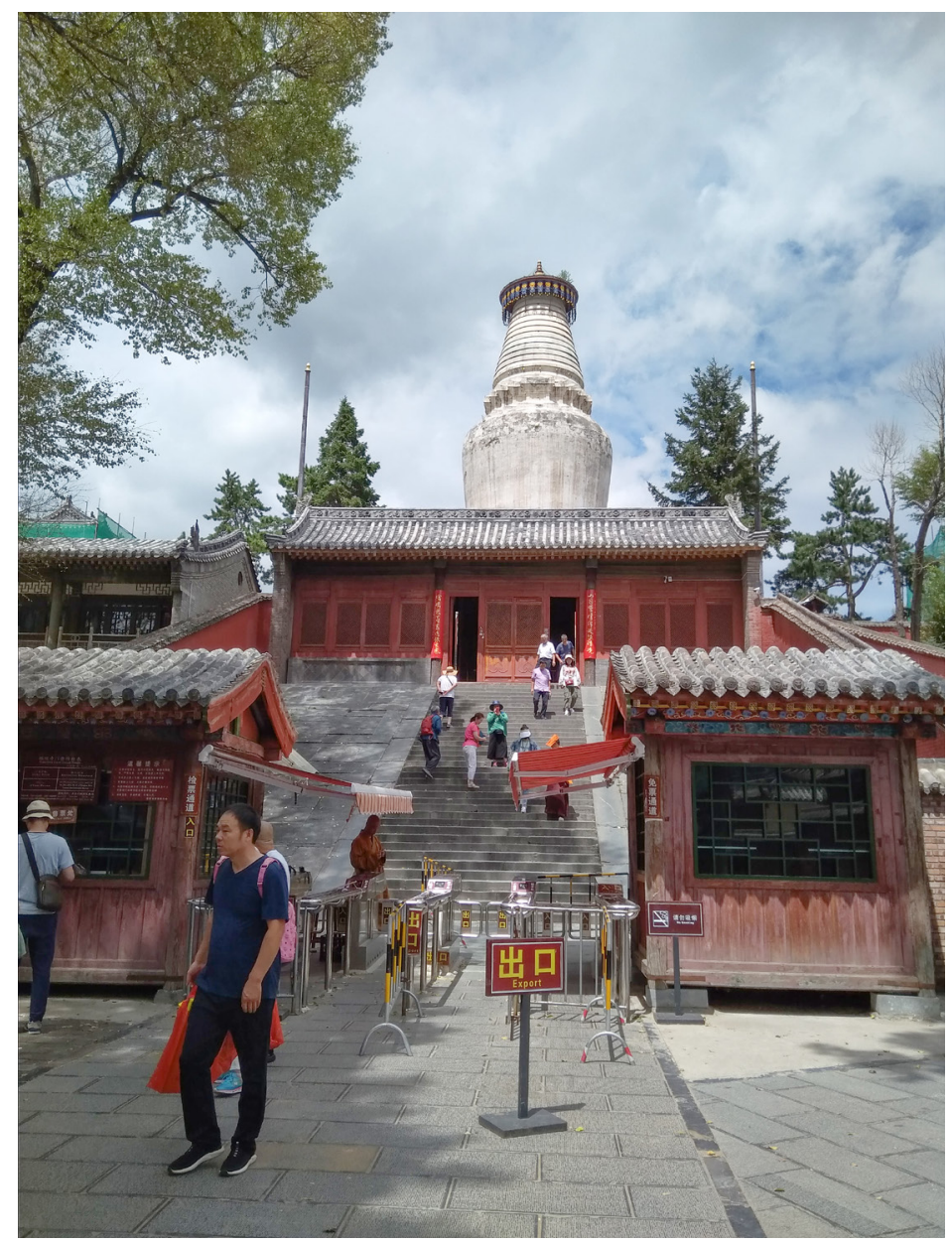

Puc. 4. Пагода Дабай — главный символ Утайшаня. 2019. Фото автора

[Fig. 4. Dabai Pagoda is the main symbol of Wutaishan. 2019. Author's photo] 
дициям китайской буддийской архитектуры, в которых либо расположены большие молитвенные цилиндры (бур. хүрдэ), либо кто-то из монахов принимает посетителей, проводит беседы с верующими.

В окрестностях пагоды Дабай произрастают леса, где на периферии территории комплекса находятся маленькие строения, в которых могут находиться сакральные объекты, например, священный камень под крышей, где верующие молятся, заодно и отдыхают. На выходе из храма, на аллее, прямо на пешеходных тротуарах величественно восседают одинокие монахи (читают мантры), при этом никто из мимо проходящих посетителей не делает подношения монахам, возможно, чтобы не отвлекать их от чтения мантр. В российской практике религиозных центров, в частности в Бурятии, такого явления среди буддийских монахов нет. Судя по территории и общему виду, организация пребывания туристов и паломников осуществляется на достойном уровне.

После посещения пагоды Дабай, по пути к храму Наньшань, мы оказались в храмовом комплексе, находящемся на противоположном берегу речки. Согласно информации на объекте, в центре этого храма находится зал Шакьямуни, который представляет собой помещение шириной $15,1 \mathrm{M}$, глубиной 14,5 м. Со всех четырёх сторон есть коридор с отдельными входами, в центре зала находится статуя «Три Святых Аватамасака» (Шакьямуни, Манджушри Бодхисаттва, Самантабхадра).

В задней части зала находится статуя старого Манджушри с седой бородой и седыми волосами. Это создает оживлённую атмосферу среди паломников, потому что изваяние отличается от всех других в Утайшане. По обе стороны стены расположены скульптуры восемнадцати архатов, включая статую Махамайи - матери Шакьямуни, которая является единственным изваянием женщины-архата на горе Утайшань [ПМА: инф. 2].

По пути мы также посетили Храм трех Будд, который включает в себя помещение, состоящее из пяти залов, имеет фронтальные комбинированные колонны и профили с одноэлементными профилями и резьбой, а также широкое переднее крыльцо. В одном из залов есть освященная статуя Три- кала Будды. Есть цветные статуи шестнадцати архатов с обеих сторон, все они имеют выступающие брови, видный нос и глубоко посаженные глаза, их рты открыты, возможно, для показа зубов. Во дворе этого храма растут деревья. Наше внимание привлекли свисающие на ветках этих деревьев кусочки ткани - красные ленты (рис. 5). В Бурятии существует такая же традиция развешивать цветные полоски ткани на деревьях в качестве подношений, к примеру, такие цветные ленты хоринцы называют зурам, окинцы зурамһан, а баргузинцы - сэмэлгэ.

Через 300 м, шагая вниз по дороге, мы оказались на берегу озера (200 м в длину и в ширину). Место тихое, идеальное для отдыха и созерцания, особую атмосферу и красоту придавала пара десятков белых птиц. Было ощущение, что храм Наньшань где-то поблизости. После кратковременного отдыха мы двинулись дальше в путь, но только под вечер, пройдя более 5-7 км, удалось найти долгожданный объект и устроиться в местной гостинице у подножия храма. Весь третий день мы провели в монастыре Наньшань, осматривая большой буддийский храм, поднимаясь вверх, осматривая залы, т. е. осваивая террасы - их оказалось семь (рис. 6).

Согласно официально распространяемой среди туристов и паломников информации, расположенный на южном склоне в 3,5 км от города Тайхуай храм Наньшань является одним из десяти важнейших храмов горы Утайшань. Храм Наньшань был построен в 1295 г. Император Чэнцэн представил храм верующим под названием «Храм Святого Дав(я)ан Югуо». Это был большой храм, хорошо известный по всей стране во время династии Юань. В 1541 г. он был отреставрирован. В более позднее время, в 1736-1795 гг. (во время правления императора Кайлонг) был подвергнут реставрации, затем, с 1877 г. по 1883 г. (с 3-го по 9-й год правления императора Гуанди династии Цин), он был реконструирован мастером Пуджи и переименован в храм Джиле (Jile Temple). A c 1912 г. по 1949 г. филантроп из Северного Китая Цзян Фучэнь перестроил и отремонтировал храм Югуо, храм Джиле и зал Шанде. Все три объекта позже были объединены и стали называться храмом Наньшань. 


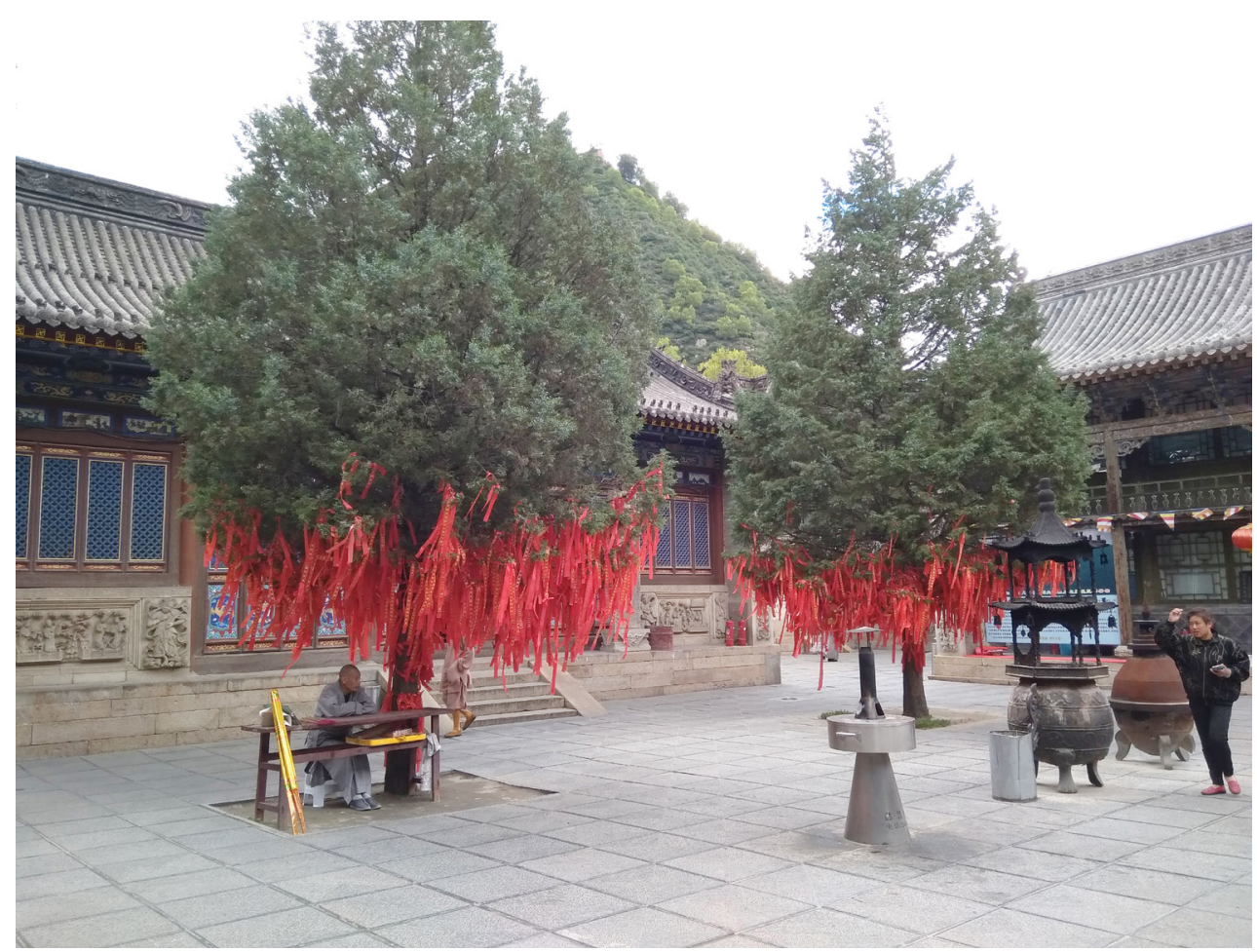

Puc. 5. Деревья во дворе храма трех Будд, увешанные красными лентами. 2019. Фото автора

[Fig. 5. Trees in the courtyard of the temple of the three Buddhas, hung with red ribbons. 2019. Author's photo]

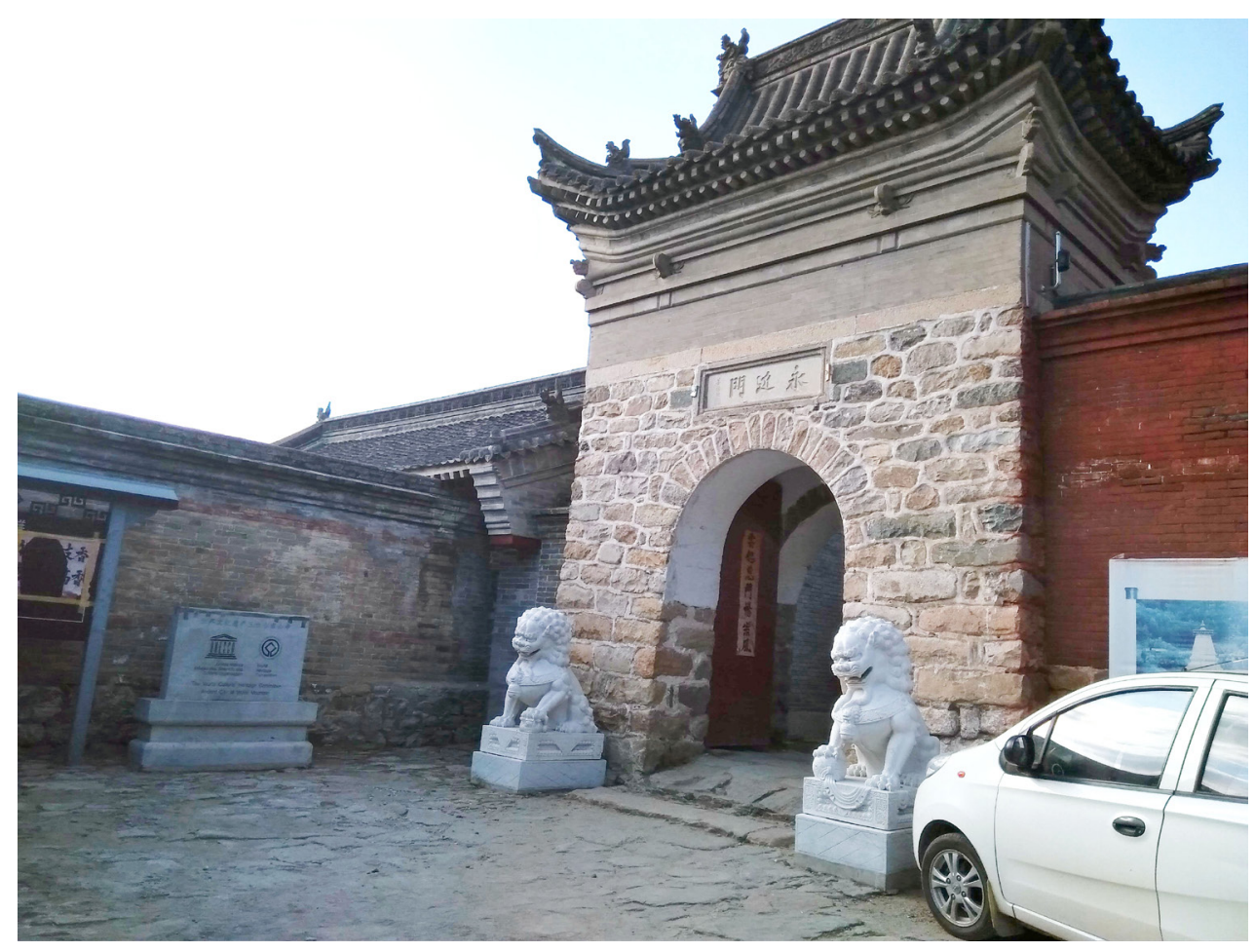

Puc. 6. Входная зона в храм Наньшань. 2019. Фото автора

[Fig. 6. Entrance zone to Nanshan Temple. 2019. Author's photo] 
Храм Наньшань занимает площадь

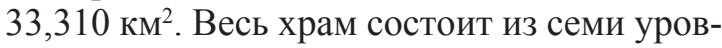
ней-террас (разделённых на три основные части). Нижняя тройка называется храм Джиле (Jile Temple), верхние три называются Югуо (Yonguo Temple) и средняя называется Шанде (Shande Hall). В Наньшане находятся 18 промежуточных залов (по курсу или маршруту) и более 300 помещений, павильонов и спасательных домов, которые встроены в горный ландшафт таким образом, чтобы сформировать следующую планировку: храм внутри храма и двор внутри двора. Храм Наньшань можно представить как выдающийся пример архитектурной планировки буддийских храмов при династиях Мин и Цин (рис. 7).

В храме в основном сохранены многочисленная каменная резьба, кирпичная резьба и каменные стелы, датируемые от поздней династии Цин до периода Китайской республики. По существу, это реликвии уникальной буддийской и местной народной культуры того времени (рис. 8).

Храм издавна славится многочисленной каменной резьбой, которая весьма популярна и почитается как современный вид народного искусства. Согласно информации, Наньшань обладает более 1480 видами каменной резьбы, которые представляют высокую художественную и историческую ценность. В 1986 г. храм Наньшань был включен в список мирового культурного наследия ЮНЕСКО, находящегося в провинции Шаньси Центрального Китая [ПМА: инф. 2].

У подножия и возле входа в храм идет бойкая торговля ритуальными предметами и сувенирами. Наиболее ходовыми товарами являются карты, схемы, изображения божеств, благовония, ленточки для привязывания, а также фаст-фуд и прохладительные напитки.

Поток верующих, паломников и туристов заполняет всю ширину дороги. Подъем в гору вынуждает людей идти пешком. Но встречаются автолюбители, в частности, таксисты, которые стараются доезжать до ворот храма. А монахи на своих машинах проезжают до пятой террасы, где у них расположена своя автостоянка. Перед входом находится гранитная стела, на которой высечена информация, что объект входит в список Всемирного наследия ЮНЕСКО.
Для любого буддиста считается хорошим предзнаменованием попасть в храм во время молебна. Когда мы вошли во двор храма Наньшань, группа верующих (предположительно китайцев) с участием восьми буддийских монахов в красных (светло-бордового цвета) одеяниях и двух монахов в коричневом одеянии обходили храм. При этом они читали мантры, сопровождая их звуками традиционных инструментов. Поразительно то, что они шли против часовой стрелки: обычно буряты и другие представители монгольского мира обходят храм по ходу движения солнца, посолонь, т. е. по часовой стрелке. После завершения круга верующие заходят вслед за монахами в зал и молятся перед большой статуей Будды, сидящего на троне. Помимо Будды на троне, с правой и левой сторон стоят маленького размера статуи, возможно, из ранга учеников. Сфотографировать не было возможности, монахи-смотрители дают знать, что это запрещено. Для удобства верующих сделаны специальные квадратные подушки высотой около 20 см, на которые они становятся на колени и совершают молитвы; затем паломники еще раз обходят статуи Будды, но уже по часовой стрелке. При попытке завязать разговор с монахом мы получили отказ в связи с отсутствием у него знания английского языка. Осталось только преподнести монаху 50 юаней, сфотографироваться с ним на память и подниматься дальше с паломниками наверх до седьмой террасы.

Храм Наньшань действительно поражает уникальными архитектурными решениями его создателей и строителей, буддийскими статуями, объектами и вспомогательными строениями. Почти в каждом дворе храма находятся в зависимости от его размеров буддийские ступы, железные вазы для воздаяния ритуальной пищи и воскурения благовония, деревья для привязывания ленточек. На каждой террасе сооружена смотровая площадка, особенно уникален вид с седьмой террасы - здесь все три ущелья Утайшаня просматриваются как на ладони (рис. 9-10).

Особым покровительством монголов с момента распространения в их среде буддизма стала пользоваться его центральноазиатская ветвь - тибетский буддизм. Еще в 1253 г. при ханском дворе появился 


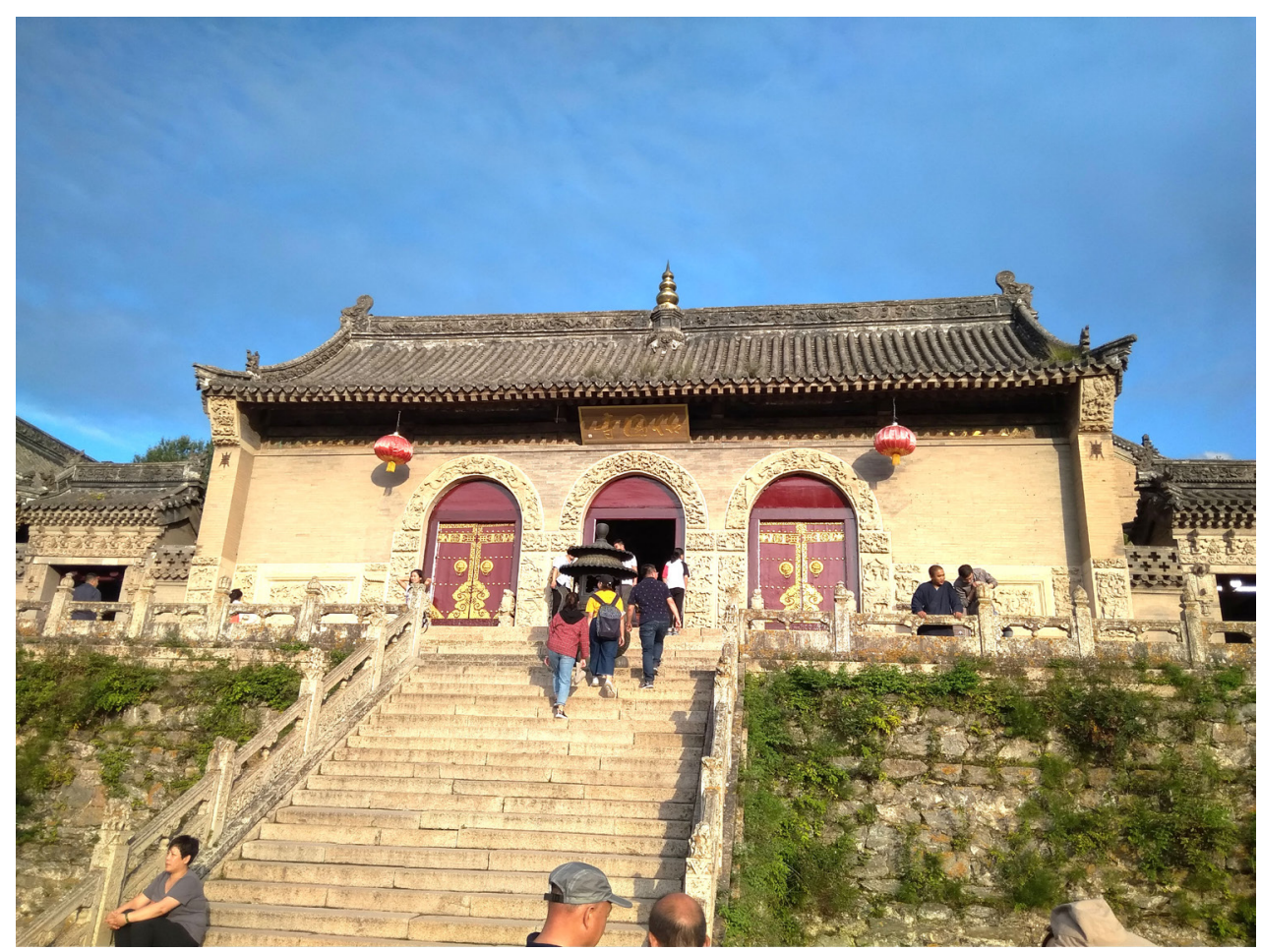

Puc. 7. Храм Наньшань, один из промежуточных залов. 2019. Фото автора [Fig. 7. Nanshan Temple, one of the intermediate halls. 2019. Author's photo]

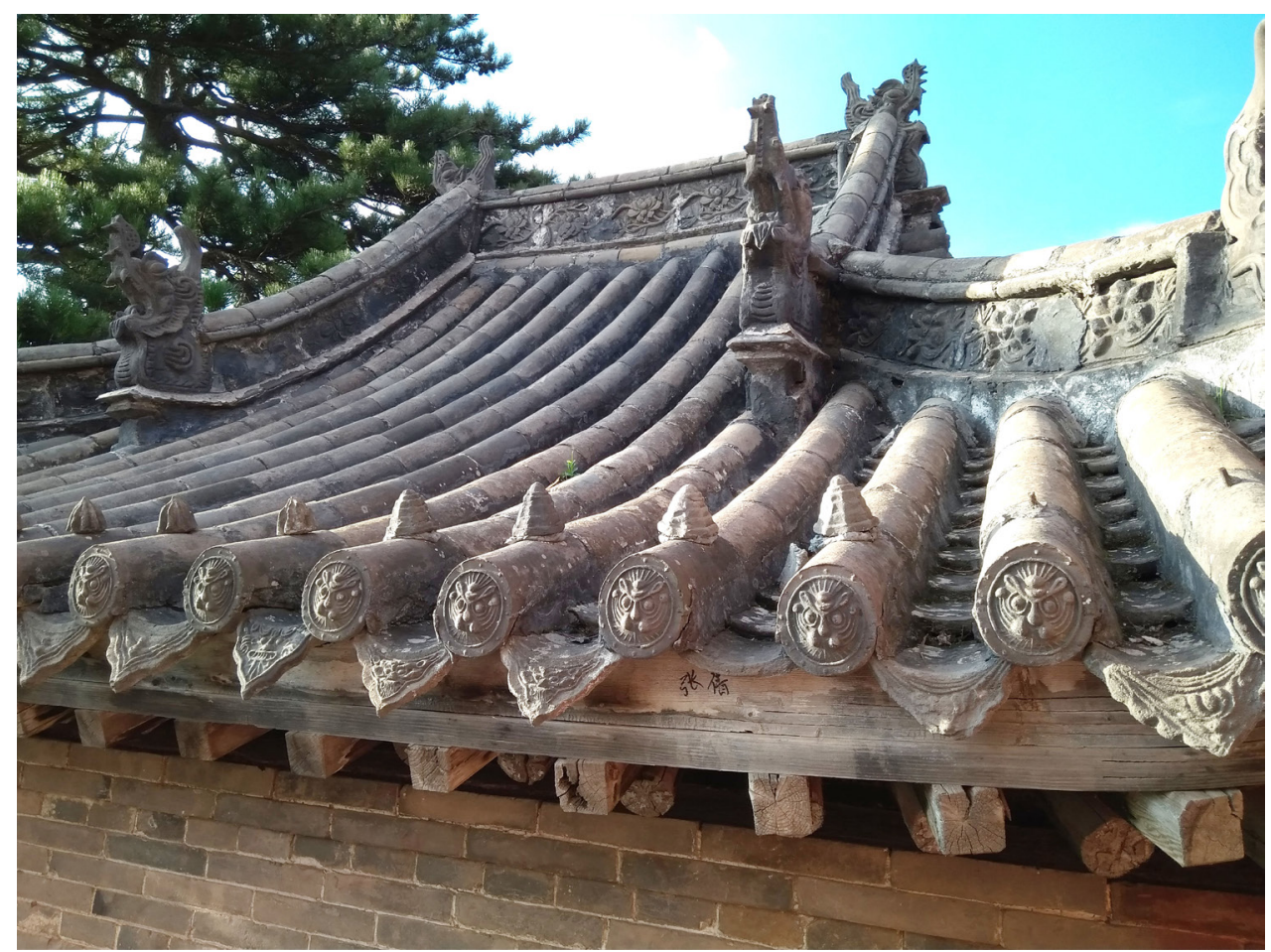

Puс. 8. Храм Наньшань. Традиционная кровля - шедевр архитектуры средневекового Китая. 2019. Фото автора

[Fig. 8. Nanshan Temple. The traditional roof is a masterpiece of the architecture of medieval China. 2019. Author's photo] 

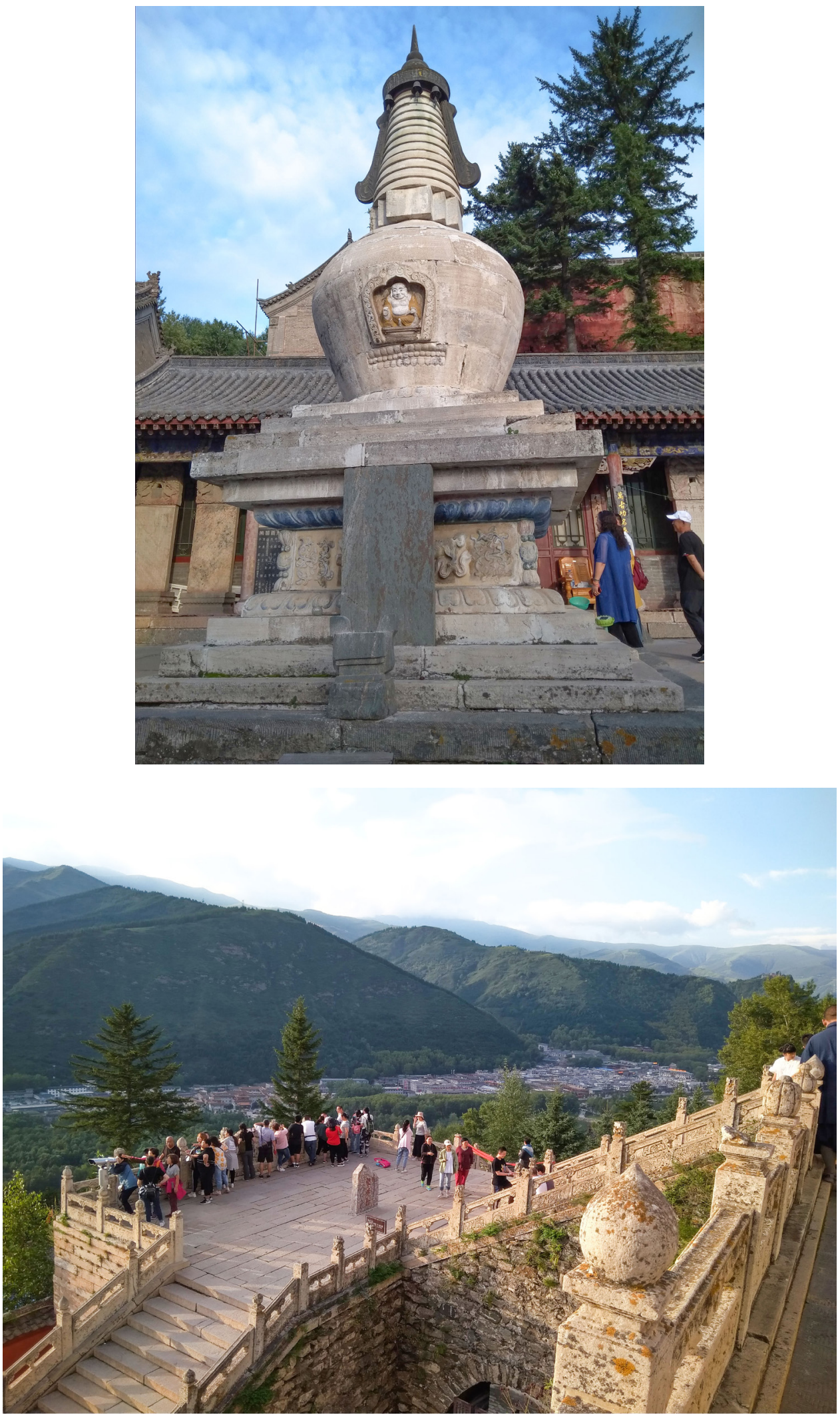

Рис. 9-10. Храм Наньшань. Буддийская ступа (5 терраса) и смотровая площадка на 6-ой террасе. 2019. Фото автора

[Fig. 9-10. Nanshan Temple. Buddhist stupa (5 terrace) and observation deck on the 6th terrace. 2019. Author's photo] 
15-летний тибетский юноша Пакс-па (Пакба-лама), знаток индийских буддийских канонов и одновременно приверженец тибетского буддизма. Пакба-лама, объявленный учителем императора, создал монгольскую квадратную письменность на основе уйгурского письма, был постоянным советником при дворе, а после смерти его прах был заключен в специально сооруженную ступу. В 1321 г. последовал указ о создании в провинциях мемориальных залов в его честь, увековечении его в скульптурных изображениях и иконографии [Кожин 2007: 180].

В религиозном отношении насаждение тибетского буддизма в среде монгольской элиты преследовало, очевидно, в тот период и цель преодоления влияния собственно китайских религий. Однако рациональные административные соображения постепенно возобладали над национальными и реформаторскими амбициями. При этом немаловажную роль играла также китаизация быта завоевателей, неизбежное явление в условиях, когда в течение жизни нескольких поколений малочисленный господствующий этнический компонент оказывается в окружении масс завоеванного населения. Еще в 1302 г. при исполнении государственных ритуалов, посвященных Шан-ди, служба шла по китайским традиционным образцам, но без присутствия императора и на монгольском языке. Однако уже в 1310 г. мемориальные жертвоприношения Чингис-хану были соединены с традиционными жертвоприношениями Шан-ди и божествам китайского имперского культа. В 1330 г. юаньский император впервые сам принял участие в исполнении государственного исторического культа. Хотя в порядке жертвоприношений, а следовательно, в иерархии божеств произошли определенные переста-

\section{Полевые материалы автора}

ПМА: инф. $1-$ Информант Толтохийн Толто, 70 лет, баргут, гор. Маньчжурия, Хайлар. Хулунбуирский аймак АРВМ КНР, запись 2010, 2011 гг.; г. Улан-Удэ, запись 2018 г.

ПМА: инф. 2 - Информант Цэрэн-Норбо, 60 лет, монгол, г. Хух-Хото. АРВМ КНР. Запись 2019 г.

ПМА: инф. 3 - Информант Амагзаев Александр Ильич, 61 год, бурят, г. Иркутск. Запись 2019 г. новки, было очевидно, что монгольские власти осознали значимость традиционного ритуала для подтверждения легитимности своей власти [Кожин 2007: 181-182].

\section{Заключение}

Буддийский сакральный центр Утайшань почитался представителями монгольских народов, в частности баргутами, бурятами. Традиция сохранялась в XX в., продолжается и в XXI в. В результате исследования описаны буддийские культовые объекты, выявлены историко-культурные связи и религиозно-мифологические параллели священных гор Утайшаня с другими сакральными объектами Восточной и Северной Азии, в частности, между Утайшанем и Лхасой, Алханаем и Утайшанем, Хулунбуиром и Утайшанем. Зафиксирован личный опыт ознакомления с современной практикой поклонения священным горам и буддийским святыням Утайшаня.

Согласно религиозной традиции, указанные объекты, начиная особенно с Юаньской династии, оказали огромное влияние на развитие буддизма в контексте этнокультурных традиций монгольского мира. Изучение религиозных традиций у таких племен, как чахары, баргуты, хорчины, шилинские монголы и другие представители этнических групп Автономного района Внутренней Монголии, проживающих на трансграничных с центральными провинциями Китая территориях, представляет большие перспективы для продолжения исследований. Отметим, что последующие поездки в изучаемый район (АРВМ Китая) дадут дополнительные материалы в изучении религиозной традиции баргутов и бурят, мифологических и исторических особенностей в контексте понимания всего буддийского наследия в целом.

\footnotetext{
Бакаева 2008 - Бакаева Э. П. Калмыцкий буддизм: история и современность // Религия в истории культуре монголоязычных народов России / сост. и отв. Н. Л. Жуковская. М.: Вост. лит., 2008. С. 161-200.

Гомбоев 2015 - Гомбоев Б. Ц. Старые и новые баргуты Внутренней Монголии Китая: специфика буддийских локальных традиций // Религии в изменяющемся мире: сб. науч. ст. / отв. ред. Э. А. Николаев. Улан-
}

Литература 
Удэ: Изд-во Бурятского гос. ун-та, 2015. C. 85-93.

Ермакова 1998 - Ермакова T. В. Буддийский мир глазами российских исследователей XIX - первой трети XX века (Россия и сопредельные страны). СПб.: Наука, 1998. $340 \mathrm{c}$.

Жуковская 2013 - Жуковская Н. Л. О буддизме и буддистах. Статьи разных лет. 1969-2011. М.: Ориенталия, 2013. 480 с.

Кожин 2007 - Кожин П. М. Историческое развитие религиозной ситуации // Духовная культура Китая. Энцикл. в 5 т. Т. 2. Мифология. Религия. М.: Вост. лит., 2007. С. 172189.

Кузнецова 2008 - Кузнецова А. И. Буддийские организации Москвы // Религия в истории культуре монголоязычных народов России / сост. и отв. Н. Л. Жуковская. М.: Вост. лит., 2008. C. 256-292.

Кузьмин 2014 - Кузьмин Ю. В. Д. П. Першин - этнограф, краевед, исследователь монгольских народов // Иркутская школа монголоведения (XVIII-XX вв.) / Ю. В. Кузьмин, В. В. Свинин; под науч. ред. проф. А. П. Суходолова. Иркутск: Изд-во БГУЭП, 2014. C. 86-95.

Лепехов 2007 - Лепехов С. Ю. Утайшань // Духовная культура Китая. Энцикл. в 5 т. Т. 2. Мифология. Религия. М.: Вост. лит., 2007. С. 629-630.

Митруев, Воронина 2018 - Митруев Б. Л., Воронина Д. К. Первый фотограф Лхасы: публикация дневника О. Норзунова «Три поездки в Лхасу (1898-1901)» (перев. Д. К. Ворониной, коммент. Б. Л. Митруева) // Oriental Studies. 2018. № 6. С. 36-72.

Мифы народов 1991 - Мифы народов мира. Энциклопедия: в 2-х т. / гл. ред. С. А. Токарев. Т. 1. А-К. М.: Сов. энциклопедия, 1991. $671 \mathrm{c.}$

Мункуев 1965 - Мункуев Н. Ц. Китайский источник о первых монгольских ханах. Над-

\section{Author's Field Data}

Informant: Tolto Toltokhiyn, aged 70, Barga Mongol, Manzhouli (Hulunbuir Prefecture, Inner Mongolia Autonomous Region, People's Republic of China). Rec. in 2010, 2011; in 2018 (Ulan-Ude, Russian Federation). (In Mong.)

Informant: Tseren-Norbo, aged 60, Mongol, Hohhot (Inner Mongolia Autonomous Region, People's Republic of China). Rec. in 2019 (In Mong.)

Informant: Aleksandr I. Amagzaev, aged 61, гробная надпись на могиле Елюй Чу-Цая. Перевод и исследование. М.: Наука, 1965. $223 \mathrm{c}$.

Нанзатов 2016 - Нанзатов Б. 3. К вопросу о ранней этнической истории баргу-бурятской общности [электронный pecypc] // Oriental Studies. 2016. № 1. C. 99-106.

Неклюдов 2019 - Неклюдов С. Ю. Фольклорный ландшафт Монголии. Миф и обряд. М.: Индрик, 2019. 520 с.

Пространство 2008 - Пространство в традиционной культуре монгольских народов / Б. 3. Нанзатов, Д. А. Николаева, М. М. Содномпилова, О. А. Шагланова; Ин-т монголоведения, буддологии и тибетологии СО РАН. М.: Вост. лит., 2008. 341 с.

Соколовский 2011 - Соколовский С. В. В цейтноте: заметки о состоянии российской антропологии [электронный ресурс] // Laboratorium. 2011. № 2. C. 70-89.

Сыртыпова 2004 - Сыртыпова C-X. Д. Устные и письменные предания об Алхане / перевод со старомонг. «Легенды об Алхане - горе, преумножающей добродетель, обители Шри Чакрасамвары», предисловие, примечания // Культура Центральной Азии: письменные источники. Вып. 6. Улан-Удэ: Изд-во БНЦ CO PAH, 2004. С. 150-166.

Цыбиков 1919 - Цыбиков Г. Ц. Буддистъ-паломник у святынь Тибета. По дневникам, веденным в 1899-1902 гг. Изд. РГО. Пг.: 15-ая Гос. тип. Звенигородская, 1919. 472 с.

Цыбиков 1981 - Цыбиков Г. Ц. Избранные труды. Т. 1. Буддист-паломник у святынь Тибета. Новосибирск: Наука, 1981. 265 с.

Этнография 1982 - Этнография: Учебник / под ред. Ю. В. Бромлея и Г. Е. Маркова. М.: Высш. школа, 1982. 320 с.

Мягмарсамбуу 2018 - Мягмарсамбуу Т. Г. Баргын туух, угсаатны зуй. Дэд боть (= История и этнография баргутов. Т. 2) / ред. С. Чулуун. Улаанбаатар: Соембо Принтинг, 2018. 308 c.

Buryat, Irkutsk (Russian Federation). Rec. in 2019 (In Bur. and Russ.)

\section{References}

[Ethnography]. Coursebook. Yu. V. Bromley, G. E. Markov (eds.). Moscow: Vysshaya Shkola, 1982. 320 p. (In Russ.)

[Mongolic Peoples: Space in Traditional Culture]. B. Z. Nanzatov, D. A. Nikolaeva, M. M. Sodnompilova, O. A. Shaglanova. Institute 
for Mongolian, Buddhist and Tibetan Studies (Sib. Branch) of RAS. Moscow: Vostochnaya Literatura, 2008. 341 p. (In Russ.)

[Myths of the World: Encyclopedia]. In 2 vols. S. A. Tokarev (ed.). Vol. 1: A-K. Moscow: Sovetskaya Entsiklopediya, 1991. 671 p. (In Russ.)

Bakaeva E. P. Kalmyk Buddhism: past and present. In: [Mongolic Peoples of Russia: religion in History and Culture]. N. L. Zhukovskaya (comp., ed.). Miklouho-Maclay Institute of Ethnology and Anthropology (RAS). Moscow: Vostochnaya Literatura, 2008. Pp. 161-200 (In Russ.)

Ermakova T. V. [Buddhist World in the Eyes of Russian Researchers: 19 $9^{\text {th }}$ Century to 1930s (Russia and Bordering Countries)]. St. Petersburg: Nauka, 1998. 340 p. (In Russ.)

Gomboev B. Ts. Old and New Barga Mongols of Inner Mongolia (China): specific features of local Buddhist traditions. In: [Religions in the Changing World]. Institute for Mongolian, Buddhist and Tibetan Studies (Sib. Branch) of RAS. E. A. Nikolaev (ed.). Ulan-Ude: Buryat State University, 2015. Pp. 85-93. (In Russ.)

Kozhin P. M. Religious situation: historical development. In: [Spiritual Culture of China: Encyclopedia]. In 5 vols. Vol. 2: Mythology. Religion. Moscow: Vostochnaya Literatura, 2007. Pp. 172-189. (In Russ.)

Kuzmin Yu. V. D. Pershin: ethnographer, historian, Mongolist. In: Kuzmin Yu. V., Svinin V. V. [Irkutsk School of Mongolian Studies: $18^{\text {th }}$ $20^{\text {th }}$ centuries]. A. P. Sukhodolov (ed.). Irkutsk: Baikal State University of Economics and Law, 2014. Pp. 86-95. (In Russ.)

Kuznetsova A. I. Buddhist organizations of Moscow. In: [Mongolic Peoples of Russia: religion in History and Culture]. N. L. Zhukovskaya (comp., ed.). Miklouho-Maclay Institute of Ethnology and Anthropology (RAS). Moscow: Vostochnaya Literatura, 2008. Pp. 256-292. (In Russ.)

Lepekhov S. Yu. Wutaishan. In: [Spiritual Culture of China: Encyclopedia]. In 5 vols. Vol. 2: Mythology. Religion. Moscow: Vostochnaya
Literatura, 2007. Pp. 629-630. (In Russ.)

Mitruev B. L., Voronina D. K. He who was the first to take photographs of Lhasa: 'Three Journeys to Lhasa (1898-1901)', a travel diary by O. Norzunov (transl. by D. K. Voronina, comment. by B. L. Mitruev). Oriental Studies. 2018. No. 6. Pp. 36-72. (In Russ.) DOI: 10.22162/26190990-2018-40-6-36-72

Munkuev N. Ts. [Chinese-Language Source on Earliest Mongol Rulers: Inscription at Yelü Chucai's Tomb Translated and Explored]. Moscow: Nauka, 1965. 223 p. (In Russ.)

Myagmarsambuu T. G. [Barga Mongols: History and Ethnography]. Vol. 2. S. Chuluun (ed.). Ulaanbaatar: Soembo Printing, 2018. 308 p. (In Mong.)

Nanzatov B. Z. To the issue of the early ethnic history of Bargu-Buryat community. Bulletin of the Kalmyk Institute for Humanities of the RAS (Oriental Studies). 2016. No. 1. Pp. 99-106. (In Russ.) DOI: 10.22162/2075-7794-2016-23-1-99106

Neklyudov S. Yu. [Folklore Landscape of Mongolia: Myth and Ritual]. Moscow: Indrik, 2019. 520 p. (In Russ.)

Sokolovsky S. V. In time-trouble: notes on contemporary Russian anthropology. Laboratorium: Russian Review of Social Research. 2011. No. 2. Pp. 70-89. (In Russ.)

Syrtypova S-Kh. D. Oral and written tales of Alkhanay: Tale of Mount Alkhanay - Shrine of Shri Chakrasamvara That Increases Merits. In: [Central Asian Culture: Written Sources]. Vol. 6. Ulan-Ude: Buryat Scientific Center (Sib. Branch) of RAS, 2004. Pp. 150-166. (In Russ.) Tsybikov G. Ts. [Selected Works]. Vol. 1: A Buddhist Pilgrim at the Shrines of Tibet. Novosibirsk: Nauka, 1981. 265 p. (In Russ.)

Tsybikov G. Ts. A Buddhist Pilgrim at the Shrines of Tibet: Travel Notes of 1899-1902. Russian Geographical Society. Petrograd: State Publ. House 15, 1919. 472 p. (In Russ.)

Zhukovskaya N. L. [About Buddhism and Buddhists: Collected Articles, 1969-2011]. Moscow: Orientalia, 2013. 480 p. (In Russ.) 